\title{
Effects of modified DATEMs with different alkyl chain lengths on improving oxidative and physical stability of $70 \%$ fish oil-in-water emulsions
}

Yesiltas, Betül; García Moreno, Pedro Jesús; Sørensen, Ann-Dorit Moltke; Anankanbil, Sampson; Guo, Zheng; Jacobsen, Charlotte

\section{Publication date:}

2018

Document Version

Version created as part of publication process; publisher's layout; not normally made publicly available

Link back to DTU Orbit

Citation (APA):

Yesiltas, B., García Moreno, P. J., Sørensen, A-D. M., Anankanbil, S., Guo, Z., \& Jacobsen, C. (2018). Effects of modified DATEMs with different alkyl chain lengths on improving oxidative and physical stability of $70 \%$ fish oilin-water emulsions. Abstract from Nordic Lipidforum Seminar, Alesund, Norway.

\section{General rights}

Copyright and moral rights for the publications made accessible in the public portal are retained by the authors and/or other copyright owners and it is a condition of accessing publications that users recognise and abide by the legal requirements associated with these rights.

- Users may download and print one copy of any publication from the public portal for the purpose of private study or research.

- You may not further distribute the material or use it for any profit-making activity or commercial gain

- You may freely distribute the URL identifying the publication in the public portal 
Effects of modified DATEMs with different alkyl chain lengths on improving oxidative and physical stability of $70 \%$ fish oil-in-water emulsions

Betül YESILTAS ${ }^{1}$, Pedro J. GARCÍA-MORENO ${ }^{1}$, Ann-Dorit M. SØRENSEN¹ㄴ, Sampson ANANKANBIL², Zheng GUO², Charlotte JACOBSEN 1

${ }^{1}$ National Food Institute, Technical University of Denmark, Lyngby, Denmark)

2 Department of Engineering, Aarhus University, Aarhus, Denmark)

The objective of this study was to produce oxidatively and physically stable high fat (70\%) fish oil-in-water emulsions by combined use of sodium caseinate (CAS) and commercial/modified diacetyl tartaric acid ester of mono- and diglycerides (DATEM) as well as investigating the effects of alkyl chain lengths (C12 and C14) of DATEM on stability. DATEM was also modified with caffeic acid in order to increase its antioxidative effects. As it is claimed that oxidation is initiated at the oil-water interface of the emulsions, it was hypothesized that modified DATEM as a surfactant would locate at the oil-water interface and protect the lipids from oxidation by its improved antioxidant activity. It has been suggested that surfactants and proteins could be used together as an effective combination for emulsifying lipids leading to low viscous emulsions. Results indicated that modified DATEM with alkyl chain length of C14 (DATEM C14) replaced more CAS compared to modified DATEM with alkyl chain length of $\mathrm{C} 12$ (DATEM C12) from the interface in 70\% fish oil-in-water emulsion. Emulsions produced with DATEM C14 had significantly decreased amount of primary and secondary oxidation products compared to emulsions with DATEM C12. When $60 \%$ of the commercial DATEM was substituted with either DATEM C12 or DATEM C14, viscosity was significantly decreased compared to emulsions with commercial DATEM, which might make high fat emulsions` incorporation into low viscosity food systems easier. 